\title{
Provenance analysis of marble ecclesiastical elements from the extra-mural Byzantine Church of Udhruh (South Jordan)
}

\author{
Khaled Al-Bashaireh $^{1}$ (D) Fawzi Abudanah ${ }^{2} \cdot$ Mark Driessen $^{3}$
}

Received: 27 February 2019 / Accepted: 24 November 2019

(C) Springer-Verlag GmbH Germany, part of Springer Nature 2020

\begin{abstract}
The aim of this research is to assign the provenance of marble samples uncovered from the extra-mural Byzantine Church of Udhruh (Augustopolis), south Jordan. The church is a three-nave basilica that most probably was built in the fifth century CE. In later expansion phases, it was remodeled by the addition of two side chapels and several rooms. The research investigated the physical, mineralogical, and isotopic properties of twenty-four marble samples of different functions using naked eyes, lenses, and multiple analytical techniques including optical microscopy, mass spectrometry, and X-ray diffraction. The results showed that the architectural elements were made of the gray calcitic Proconnesus-1 marble (Marmara, Turkey); while the four fonts or basins were carved out of the beige dolomitic Thasos-3 marble (Thasos Island, Cape Vathy, Greece); and the small squared column of unknown function was carved out of the fine-grained white calcitic Penteli marble (Mount Pentelikon, Attica, Greece). The results indicate that the most popular supply of the ecclesial marble to the south (and north) Jordan during the Byzantine period was the gray Proconnesus- 1 . The use of white Penteli and Thasos-3 marbles were limited to ritual elements.
\end{abstract}

Keywords Ecclesiastical Marble $\cdot$ Byzantine Church $\cdot$ Provenance Investigation $\cdot$ Archaeometric Analysis $\cdot$ Udhruh $\cdot$ Jordan

\section{Introduction}

\section{Background}

The village of Udhruh, $12 \mathrm{~km}$ east of Petra (Fig. 1), had almost gone into oblivion as an archeological site until the early 1980s (Killick 1983, 1986; Abudanh 2006). Earlier explorations and excavations revealed that Udhruh housed an important Nabatean settlement and a Roman legionary fortress, and

Khaled Al-Bashaireh

khaledsm@email.arizona.edu

Fawzi Abudanah

fawziabudanh@yahoo.co.uk

Mark Driessen

m.j.driessen@arch.leidenuniv.nl

1 Department of Archaeology, Yarmouk University, Irbid 211-63, Jordan

2 Petra College for Tourism and Archaeology, Al-Hussein Bin Talal University, Wadi Musa 71810, Jordan

3 Faculty of Archaeology, Leiden University, P.O. Box 9514, 2300 RA Leiden, The Netherlands became a major center during the Byzantine and Muslim times. The Nabataean period in this region dates traditionally from the 3rd-2nd BCE till $106 \mathrm{CE}$ (the date of the establishment of the Roman Province of Arabia), although the material culture and layout of structures remain dominantly Nabataean through large parts of the 2 nd and 3 rd centuries CE. For earlier expeditions and research in Udhruh see for instance Brünnow and Domaszewski (Brünnow and von Domaszewski 1904: pp. 429-462); Glueck (1935: p. 76); Killick (1990: pp. 249 250); Al-Bashaireh (2013).

The Roman castra - with large parts of the more than 3-m wide ashlar defensive walls and inner structures still standing - form a trapezoid of four sides measuring $246 \times$ $207 \times 248 \times 177 \mathrm{~m}$ and occupies an area of about 4.7 ha in accordance with the dimensions of late Roman legionary camps. Classical literary and archeological sources point to a long-term development of the village from Nabataean till Islamic times (Fiema 2002: pp. 209-210; Kennedy and Falahat 2008; Al-Salameen et al. 2011). Literary sources make it clear that Augustopolis - as Udhruh was called during Byzantine times - gained ecclesiastical status during this period (Frösén 2004: 142). Two bishops, named Johannes of Augustopolis, attended the Ecumenical Council in Ephesus in $431 \mathrm{CE}$ and the Synod in Jerusalem in $536 \mathrm{CE}$. Elias, 


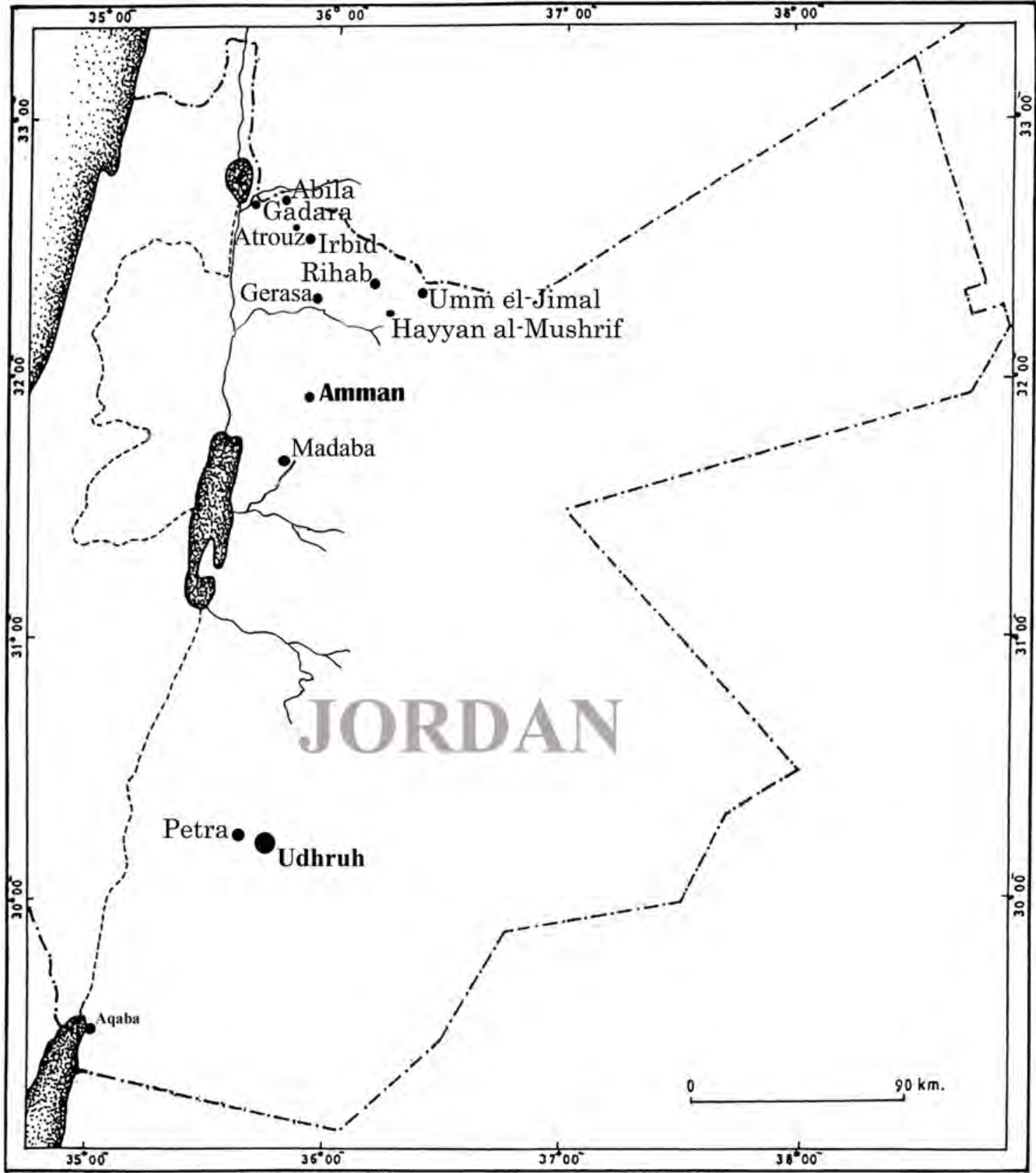

Fig. 1 Location of Udhruh and other sites mentioned in the text

diaconus et monachus Augustopolitanus, signed the decisions of the Synods in Jerusalem and Constantinople in $536 \mathrm{CE}$ (Fiema 2002: 210, and references therein). In $630 \mathrm{CE}$, Udhruh entered peacefully under Muslim's control and paid a tribute of 100 dinars (Al-Salameen et al. 2011: p. 233). It acquired a special position during this time: an important arbitration took place, at a hill just north of the village, between competing Muslim parties resulting in the establishment of the Umayyad state (al-Tabarī 1987: p. 10). A manuscript from the Sinai-peninsula written by an Egyptian monk for a priest from Udhruh shows that the village still housed a Christian community at the beginning of the tenth century (Fiema 2002: p. 211).

The archeological variety and perfect preservation of the surrounding area of Udhruh were, in combination with the intriguing site itself, essential criteria for starting a joint international archeological project between the Petra College for Tourism and Archeology of Al-Hussein Bin Talal University and the Faculty of Archeology of Leiden University in 2011. Five years of inventory fieldwork (2011-2015) revealed an actively exploited region with impressive investments in agro-hydrological intensification, building material 
procurement, communication and security networks, settlement development, and religious transformations. The 20162018 research funded by the Van Moorsel and Rijnierse Foundation, aimed at aspects of religious continuity and transformation in one of the centers of the early Muslim world, with small-scale excavations, examining the 2005 'clearance' spoil heaps, OSL and $14 \mathrm{C}$ dating, transcribing inscriptions, and making 3D-reconstructions.

\section{The Udhruh church: archeological field work, selection, and approach}

An antique extra-mural church is located about $30 \mathrm{~m}$ to the south of the southwest corner tower of the Roman fortress (Fig. 2). The church was first explored by Père A. H. Vincent during the last decade of the nineteenth century (Vincent 1898). Vincent made a drawing of the visible top parts of the walls depicting only the nave and the narthex of the church. After that visit, the church must have remained nearly untouched for another century, as can be seen on aerial photographs of 1939, 1953, 1980, and 1998. ${ }^{1}$ In 2005, the rubble of the major parts of the church was cleared away and the walls were restored by the local representative of the Department of Antiquities of Jordan. This clearance program aimed to improve the visibility, attractiveness, and accessibility of the village for tourism. Discoveries made during the rubble clearance brought the Udhruh extra-mural church to light. Several parts of its interior walls were plastered with multi-layer stucco containing Christian charcoal graffiti and have Greek and Arabic inscriptions on them. Four of the Arabic Christian inscriptions were quite complete and could be dated on the basis of the handwriting to the 13th and early 14th centuries $\mathrm{AD}$, which might indicate the coexistence of Arabic-Christian communities in Udhruh till the early days of the Mamluk Sultanate (Al-Salameen et al. 2011: pp. 234 237).

A looter hole in the core of the church allowed us to analyze the complete stratigraphy, regarding the site preparation, the foundation layers, the initial building and several renovation phases of the church. Mortar layers of its initial floor foundation contained charred twigs which were radiocarbon dated to the fifth century $\mathrm{CE}$, resulting in our hypothesis that the church was built in this century. The church is a three-nave basilica, with two pastoforia next to the apse, measuring an

\section{Udhruh Roman fortress, Jordan}

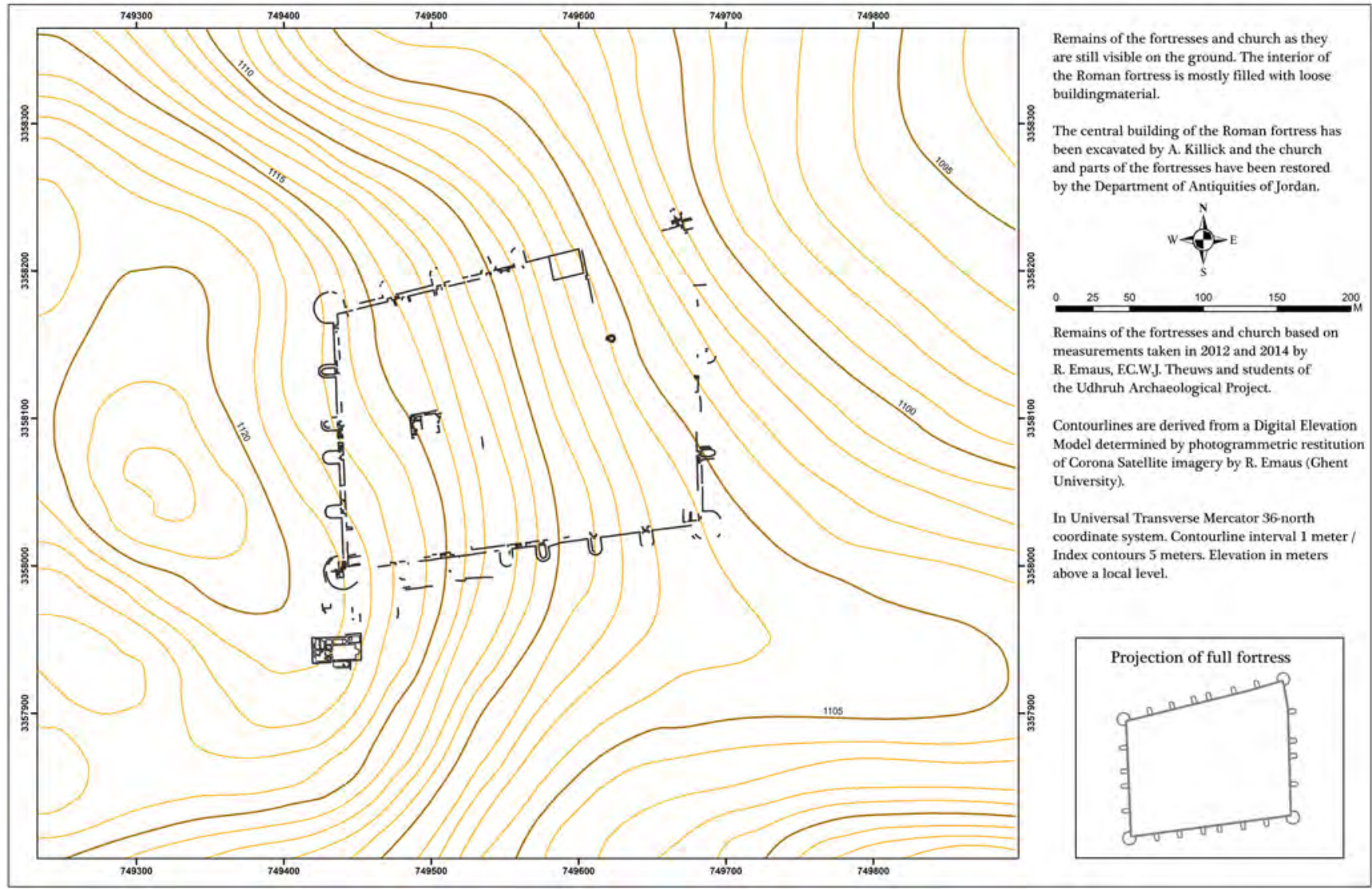

Fig. 2 Surface remains of the Udhruh Roman fortress and extra-mural church. Illustration by Roeland Emaus 


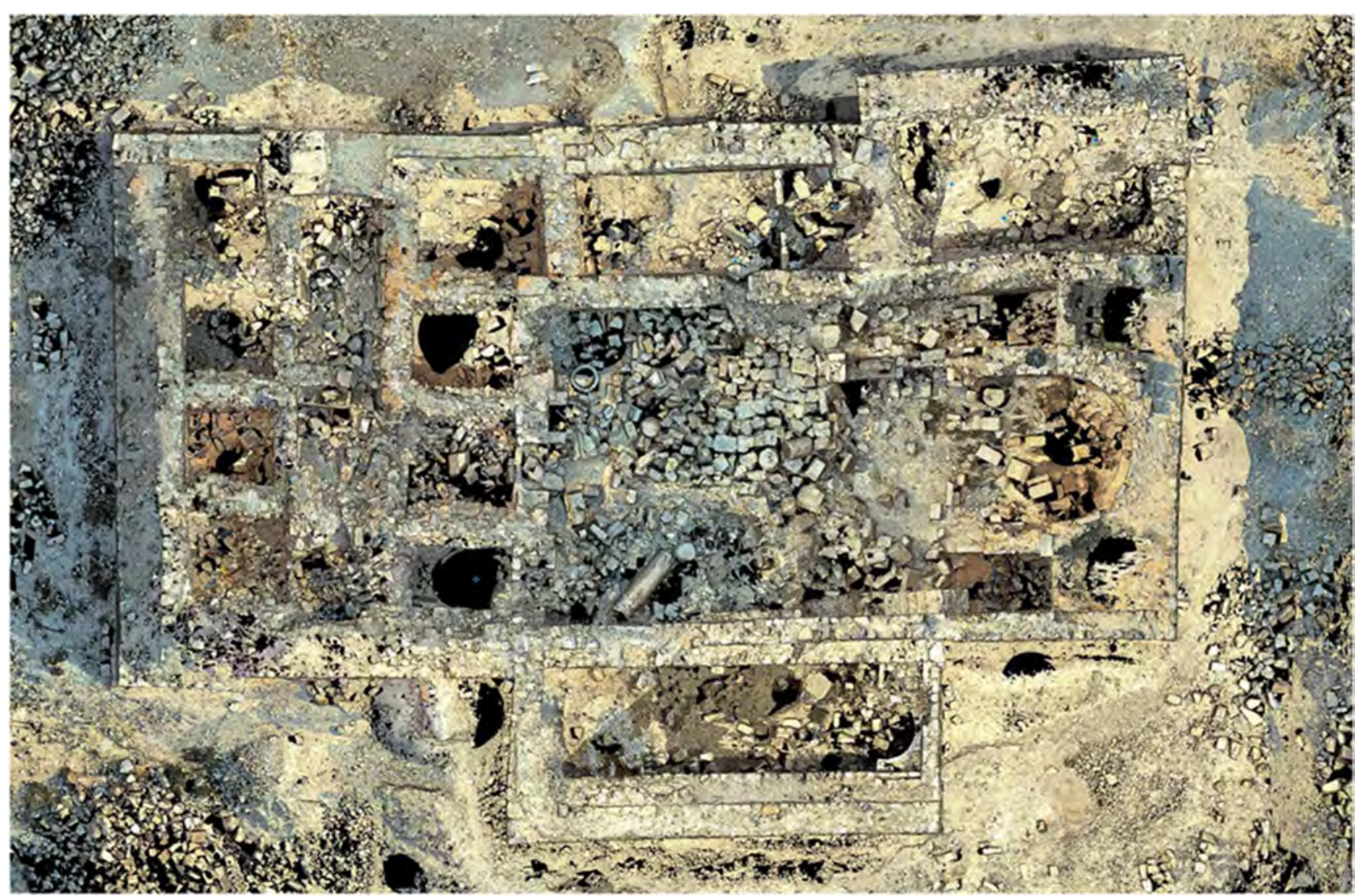

Fig. 3 Top plan of the Udhruh church (the church's length is $33.5 \mathrm{~m}$ )

area of about $20.5 \times 12.0 \mathrm{~m}^{2}$ (Fig. 3). In later centuries, two side chapels and several rooms were added during different extension phases which enlarged the church to a final area of about $33.5 \times 24.5 \mathrm{~m}^{2}$. Most of the walls are more or less complete and standing to a height of approximately $3 \mathrm{~m}$.

Throughout the last 3 years of archeological field campaigns (2016-2018), sixty marble architectural elements were discovered, of which a several dozen with a clear ecclesiastical origin; see some samples in Fig. 4. Thirty elements were found in the spoil heaps of the 2005 Department of Antiquities of Jordan clearance, twenty elements were stray/ surface finds, and the remainder were retrieved during the excavations. It is worth noting that none of the marble elements were in situ or could be located to their initial location; the church has been modified several times in the span of its usage. The excavated filling layers inside the church date to Mamluk and post-Mamluk times. All marble elements were however (originally) retrieved from within the perimeters of the Udhruh extra-mural church. We think that a secondary use of these marble elements coming from another location than the church, for instance originally applied within the Roman legionary fortress, can be ruled out. This because no marble fragments or elements have been excavated nor found as surface finds within the walls of this adjacent Roman fort or at another location in Udhruh, besides the extra-mural church. At several locations in the apse, imprints of marble altar screens - matching the sizes of retrieved marble elements could be observed in the original mosaic floor. In 2018, an altar of a later church phase was excavated, made of spolia coquina limestone blocks, which was constructed on top of this mosaic floor in the center of the apse. Accordingly the hypothesis is that the church was furnished with the imported marble elements during the initial or one of its early phases. Although the original context of many of the studied marbles is unclear, sourcing these materials adds to the late antique studies of marble exploited in the decoration of Udhruh's church, and possible distribution networks involved in the building of such churches in Southern Jordan.

Sourcing ecclesial marble has gained an increasing attention during the past years in Jordan. The archaeometric analyses of the chancel screen marbles from Rihab churches by Al-Bashaireh and Al-Housan (2015) showed that the primary source of the marble was Marmara Island (Proconnesus-1), Turkey, and the secondary source was Docimium, modern Iscehisar (Turkey). Al-Bashaireh and Lazzarini (2016) showed that the Proconnesus-1 marble was the dominant marble used in the construction of the Cruciform church at Abila. Similarly, Al-Bashaireh and Dettman (2015) found the same 


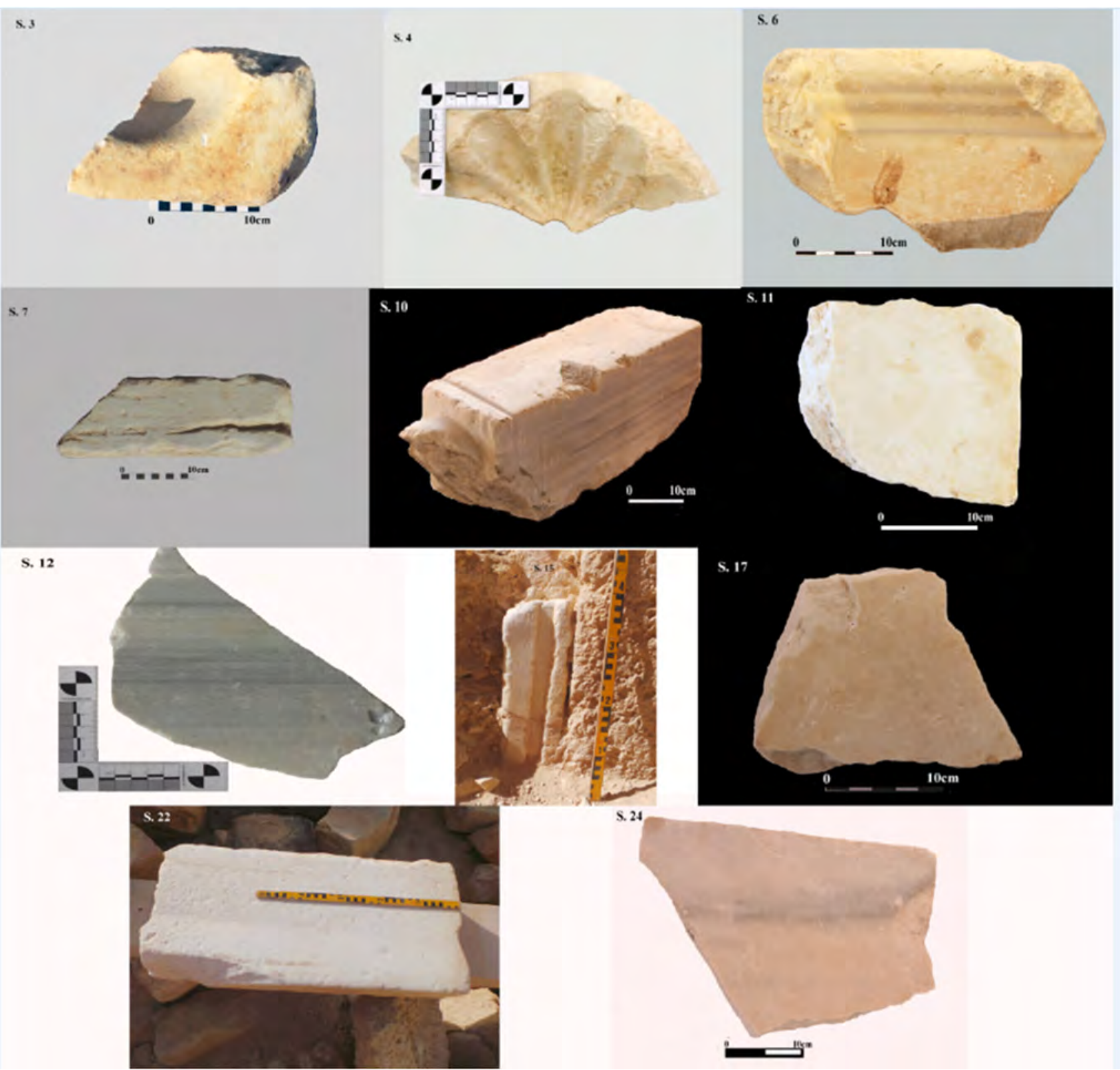

Fig. 4 Representative samples of the Udhruch church collection

result by analyzing marble samples from three churches in north Jordan (the Umm el-Amad church and Area B church at Abila, and Atrouz church west Capitolias). Most of the marbles used at the middle church of Hayyan al-Mushrif, Mafraq were Proconnesus-1 marble (Al-Bashaireh and AlHousan 2019).

This research uses different analytical methods to characterize marble samples collected from ecclesiastical elements from the extra-mural Byzantine church of Udhruh (South Jordan) in order to determine their source. Multiple analytical methods are usually used to an unambiguous assignment of marble provenances and to overcome the overlapping of analytical results of some quarries used in antiquity.

\section{Samples and methods}

Twenty-four different broken architectural elements of different functions were selected for analysis. Representative small chips or fragments were detached from already broken pieces or surfaces of these elements using sharp chisels and light hammer to maintain their esthetic appearance unaffected. The architectural elements are listed and described in Table 1, and some of the samples are presented in Fig. 4.

The samples were characterized by multiple analytical techniques. X-ray diffraction (XRD) analyses determined the mineralogical composition of the samples. XRD 


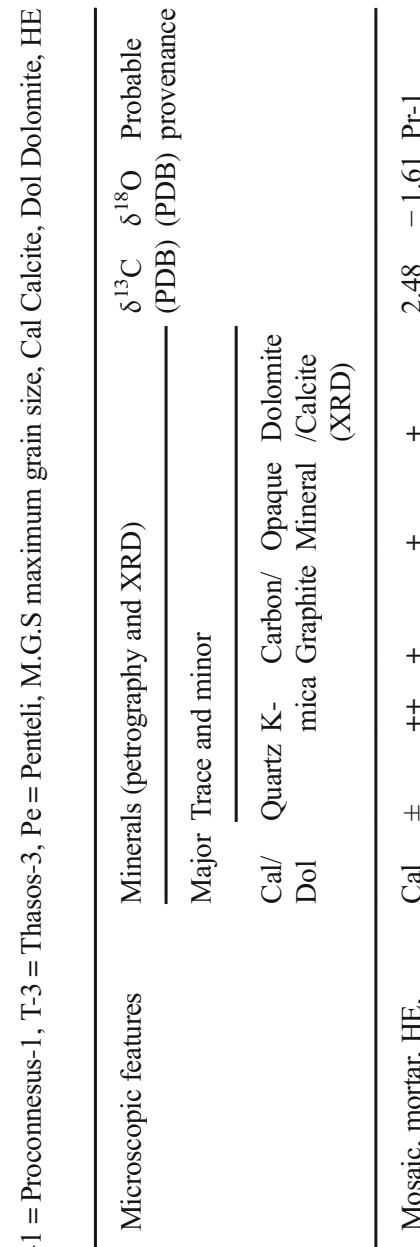

站

突

วิे

용

।

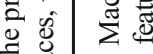

壹

宅

跣

त्.

突

สิ

훙

응

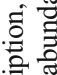

焉要

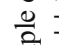

丠.

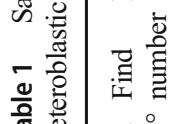

\begin{tabular}{|c|c|c|c|c|c|c|c|}
\hline \pm & $\stackrel{m}{H}$ & 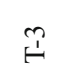 & 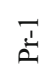 & $I$ & $\stackrel{0}{2}$ & $I$ & I \\
\hline$\underset{i}{\hat{i}}$ & 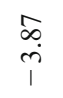 & तે & $\begin{array}{l}\vec{n} \\
\stackrel{+}{1}\end{array}$ & $\underset{i}{i}$ & $\stackrel{R}{i}$ & $\stackrel{\substack{n \\
i}}{i}$ & $\stackrel{\text { fo }}{i}$ \\
\hline $\begin{array}{l}\stackrel{\infty}{\text { i }} \\
\text { ind }\end{array}$ & $\stackrel{\tilde{m}}{\dot{m}}$ & $\stackrel{\circ}{m}$ & $\begin{array}{l}\stackrel{n}{n} \\
\ddot{n}\end{array}$ & $\stackrel{m}{m}$ & $\underset{+}{\stackrel{o}{+}}$ & $\stackrel{\infty}{\infty}$ & Ç \\
\hline
\end{tabular}

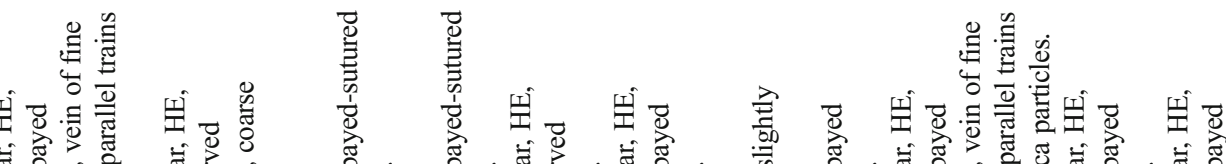

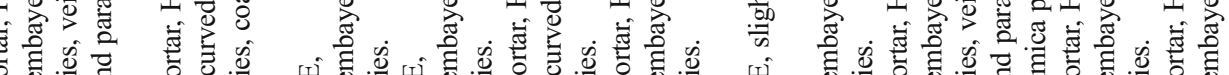

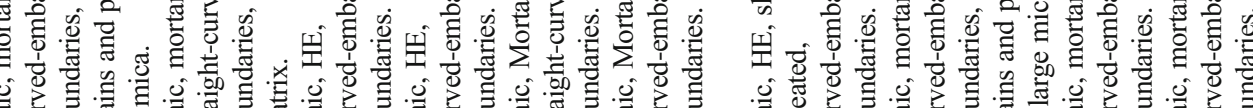

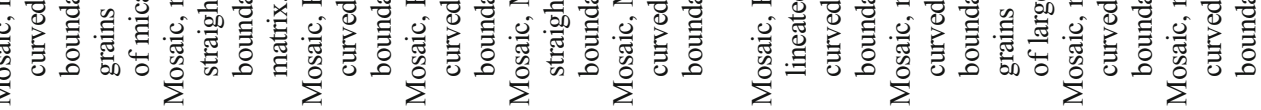

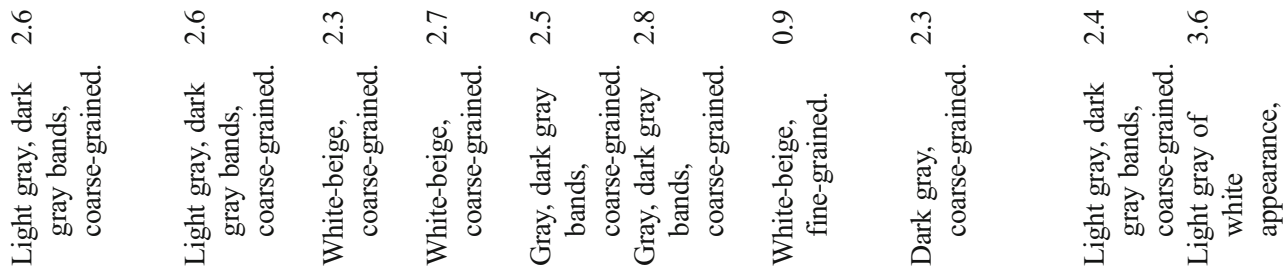

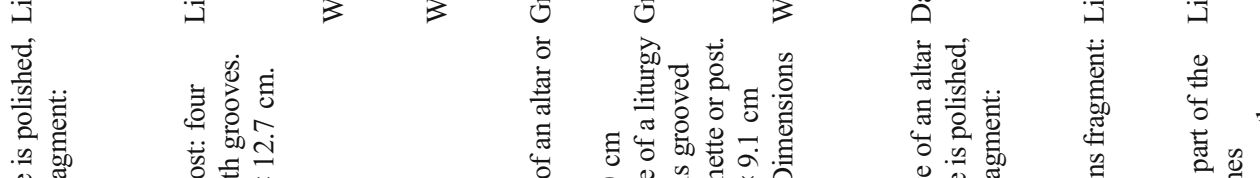

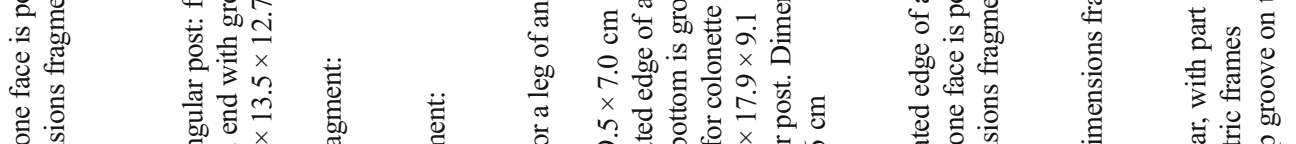

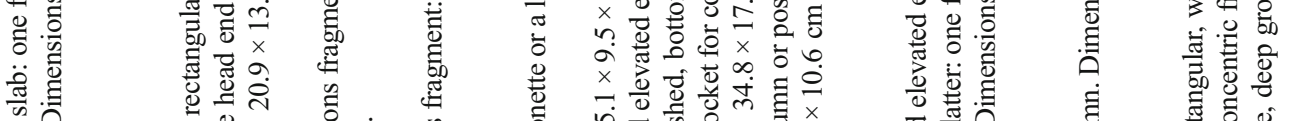

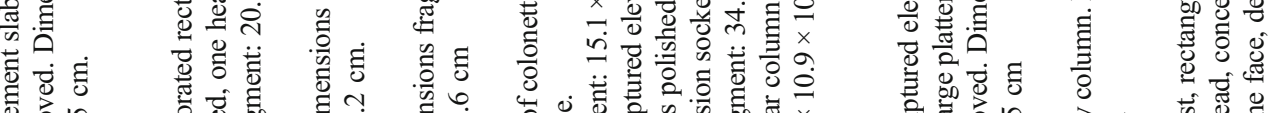

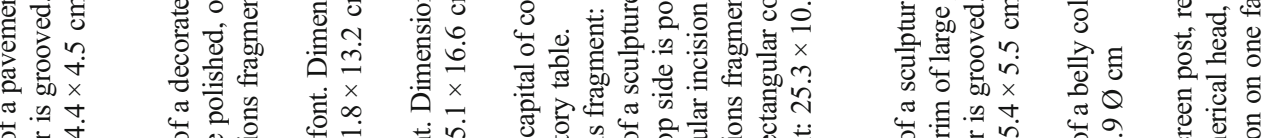

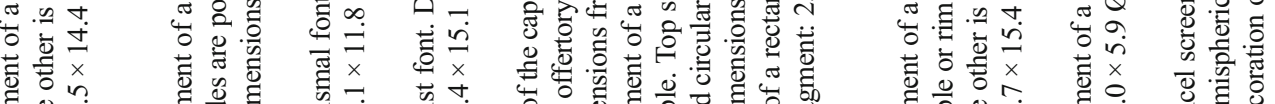

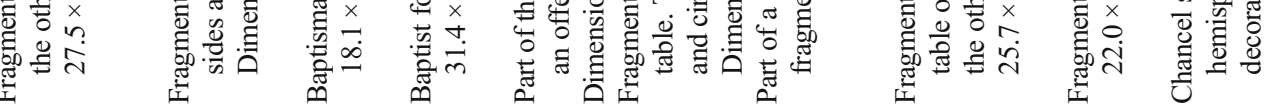




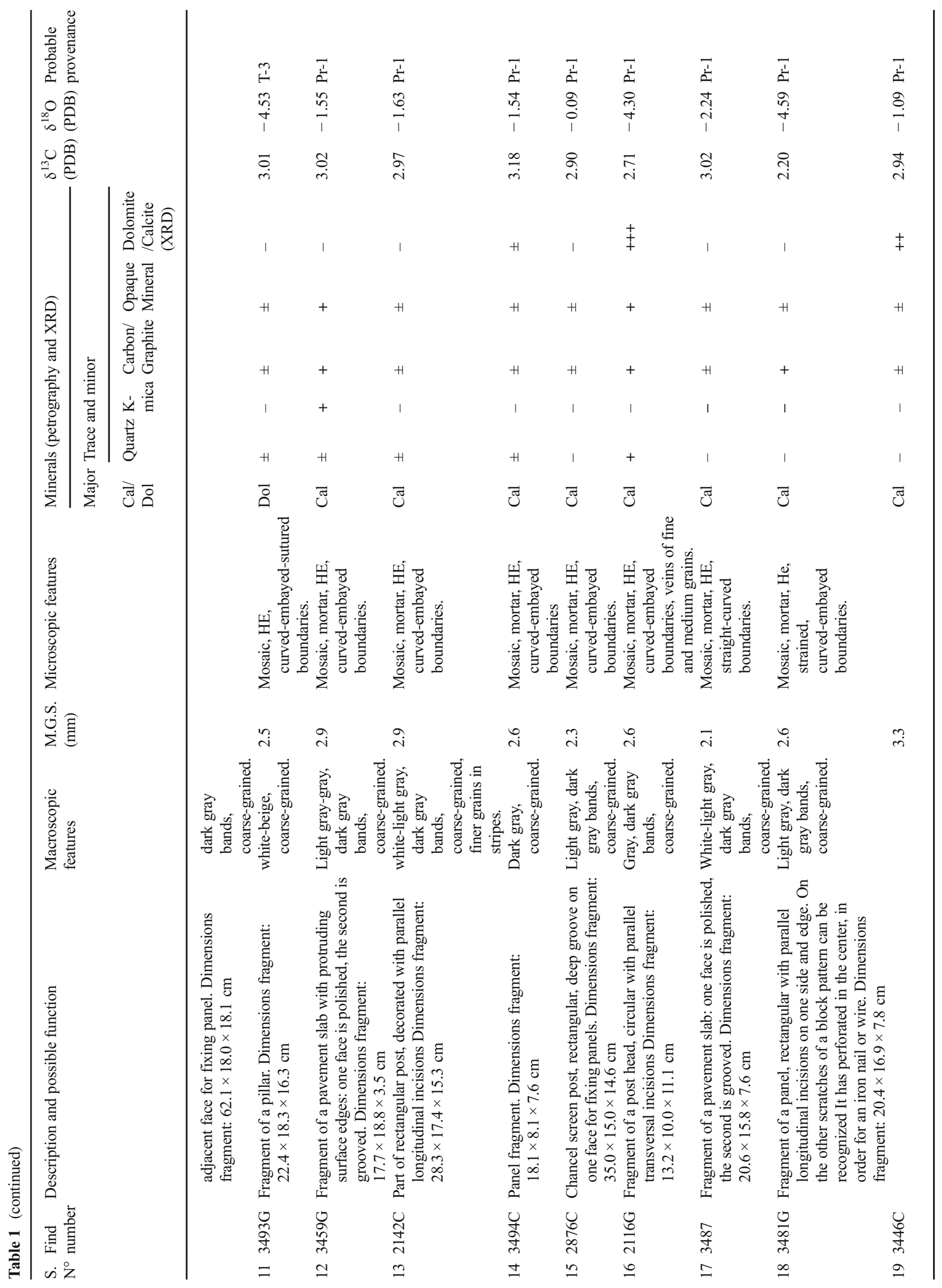




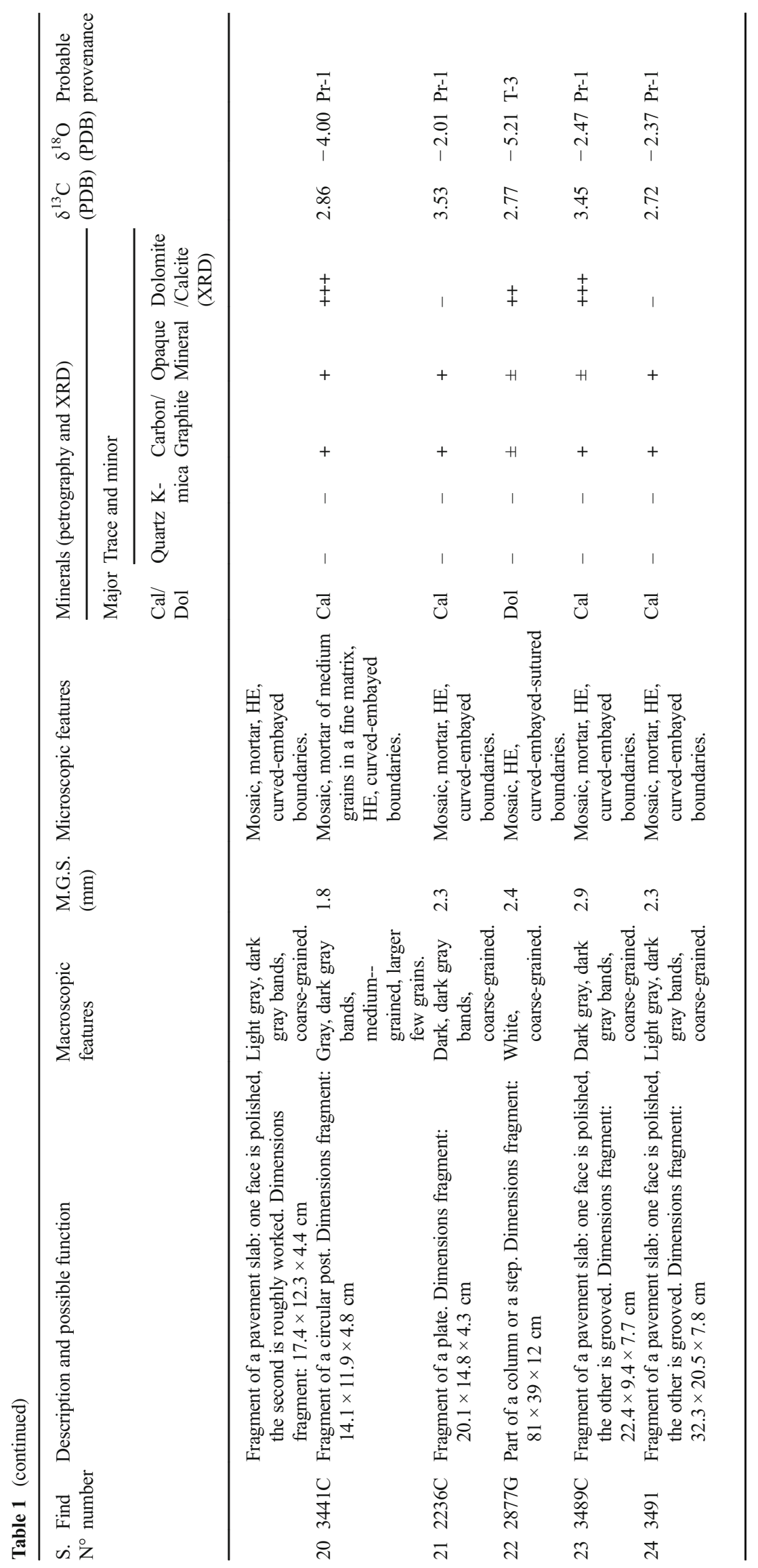


analyses were carried out on powders from whole samples using a Shimadzu Lab X, 6000 X-ray diffractometer. Powder diffraction patterns were obtained under the following conditions: $\mathrm{CuK} \mu$ radiation $(1.5418 \AA)$ with $30 \mathrm{kV}$ and $30 \mathrm{~mA}$ energy.

Optical microscopy (OM) of thin sections studied a number of petrographic parameters of important diagnostic significance for provenancing marble, including: fabric, maximum grain size (MGS), and grain boundary shapes (GBS) of calcite or dolomite grains and the distribution of accessory minerals (Gorgoni et al. 2002; Lazzarini 2004; Gaggadis-Robin et al. 2009). Thin section analyses were performed using a Leitz 7062 model polarizing microscope. XRD and OM analyses were carried out at the laboratories of the Faculty of Archeology and Anthropology at Yarmouk University.

Mass spectrometry (MS) analyses measured the samples' $\delta^{13} \mathrm{C}$ and $\delta^{18} \mathrm{O}$ values on powders of whole samples using an automated carbonate preparation device (KIELIII) coupled to a gas ratio mass spectrometer (Finnigan MAT 252). The precision of the isotopic ratio is $\pm 0.1 \%$ o for $\delta^{18} \mathrm{O}$ and $\pm 0.08 \%$ or $\delta^{13} \mathrm{C}$ ( 1 sigma); the measurements were calibrated based on repeated measurements of NBS-19 (TS-limestone) and NBS-18 (calcite). The values of isotopic composition were expressed in terms of $\delta^{13} \mathrm{C}$ and $\delta^{18} \mathrm{O}$, in $\%$, relative to the international reference standard Pee Dee Belemnite (Craig 1957). Isotopic measurements were carried out at the Environmental Isotope Laboratory of the Department of Geosciences at the University of Arizona in Tucson.

A few milligrams of cleaned portion of each chip were ground to powders and used for XRD and MS analyses, while the rest of the chips produced thin sections for OM analyses.

The analytical data collected were compared with the main reference databases of Mediterranean marbles exploited in antiquity (Gorgoni et al. 2002; Attanasio et al. 2008; Antonelli and Lazzarini 2015). The isotopic signatures were plotted against the Antonelli and Lazzarini (2015)'s updated global isotopic reference diagram.

\section{Results}

The studied samples range in color from beige to light and dark gray. Darker gray parallel bands or spots are visible in most of the samples (Fig. 4, Table 1). Function, color, and analytical results are presented in Table 1 . The mineralogical composition of the samples analyzed by XRD divides the samples into dolomitic $(3,4,11,22)$ and calcitic samples (the rest of the samples).

\section{The dolomitic marbles}

Four white beige and coarse-grained samples belong to the dolomitic group $(3,4,11,22)$. It is agreed that the white beige and coarse-grained dolomitic marble was mainly quarried in ancient times from Thasos-3 Island especially for sculptures (Herrmann and Newman 2002). Isotopic signatures of the four samples sit within the isotopic region of Thasos-3 dolomitic marble, but within other isotopic regions of ancient marble quarries (Fig. 5). Microscopically, the samples show microstructure features similar to those of Thasos- 3 dolomitic marbles including mosaic fabric, heteroblastic texture, curved to sutured grain boundaries, deformed polysynthetic twinning, and a MGS range between 2.1 and $2.5 \mathrm{~mm}$ (Fig. 6) (Bruno et al. 2002a). All of these data affirm that the samples most probably originated from Thasos- 3 dolomitic marble (the district of Cape Vathy), Thasos Island, Greece.

\section{The calcitic marbles}

Twenty samples $(1,2,5,6,7,8,9,10,13,14,15,16,17,18$, $19,20,21,23,24,25)$ consist mainly of calcite concerning their mineralogical composition and minor dolomite, while others show parallel trails of muscovite (Fig. 6, Table 1). Depending on the maximum grain size values, only sample (7) is fine grained, while the rest of the calcitic samples are medium to coarse-grained (Table 1).

\section{The fine-grained marbles}

Only sample 7 belongs to this group. The isotopic analyses represented in Fig. (5) indicate that sample 7 originated from Penteli fine-grained marble because its isotopic values are only located within the Penteli isotopic region. Penteli provenance is also supported by the sample's petrographic features seen under the polarized microscope (Fig. 6). The fine grains are lineated and euhedral, have curved to straight boundaries, and form heteroblastic and mosaic textures (Roos et al. 1988).

\section{The coarse-grained marbles}

Nineteen samples $(1,2,5,6,8,9,10,12,13,14,15,16,17$, $18,19,20,21,23,24)$ belong to this group. The isotopic signatures of these samples are located in different isotopic regions of ancient marble quarries (Fig. 5). However, all the signatures are comprised in the Proconnesus-1 isotopic region. They have heteroblastic fabric, curved, embayed to sutured grain boundaries, a MGS between 2.1 and $3.6 \mathrm{~mm}$, and the typical mortar texture of the Proconessus-1 marble. Some samples have distinct features; for instance, samples $1,8,16$, and 20 have two grain-size distributions; samples 1 and 8 show trains of muscovite; sample 10 has the largest MGS $(3.6 \mathrm{~mm})$, and sample 18 has elongated large calcite crystals 
Fig. 5 The isotopic signatures of the marbles from Udhruh extramural Byzantine Church plotted in the $\delta^{18} \mathrm{O}-\delta^{13} \mathrm{C}$ diagram of Antonelli and Lazzarini (2015) for the main Mediterranean fine(a) and medium-coarse-grained (b) marbles used in antiquity. $\mathrm{C}$ Carrara; Pe Penteli; Doc Docimium; Pa-1 Paros-1 (Lychnites, Stephani), Hy Hymettus, GKT Göktepe, N Naxos; Pr Proconnesus (Pr-1 Proconnesus from Saraylar; $\mathrm{Pr}-2$ Proconnesus from Camlik); Aph Aphrodias;, Pa Paros (Pa-2 Chorodaki valley; Pa-3 Agios Minas valley); T Thasos (T-1 district of Phanari; T-2 district of Aliki; Thasos-(1) 2: this domain comprises the vast quarrying district of Alikı' (Thasos-2) and the small extraction site of Phanari (Thasos-1); T-3 district of Vathy-Saliara)
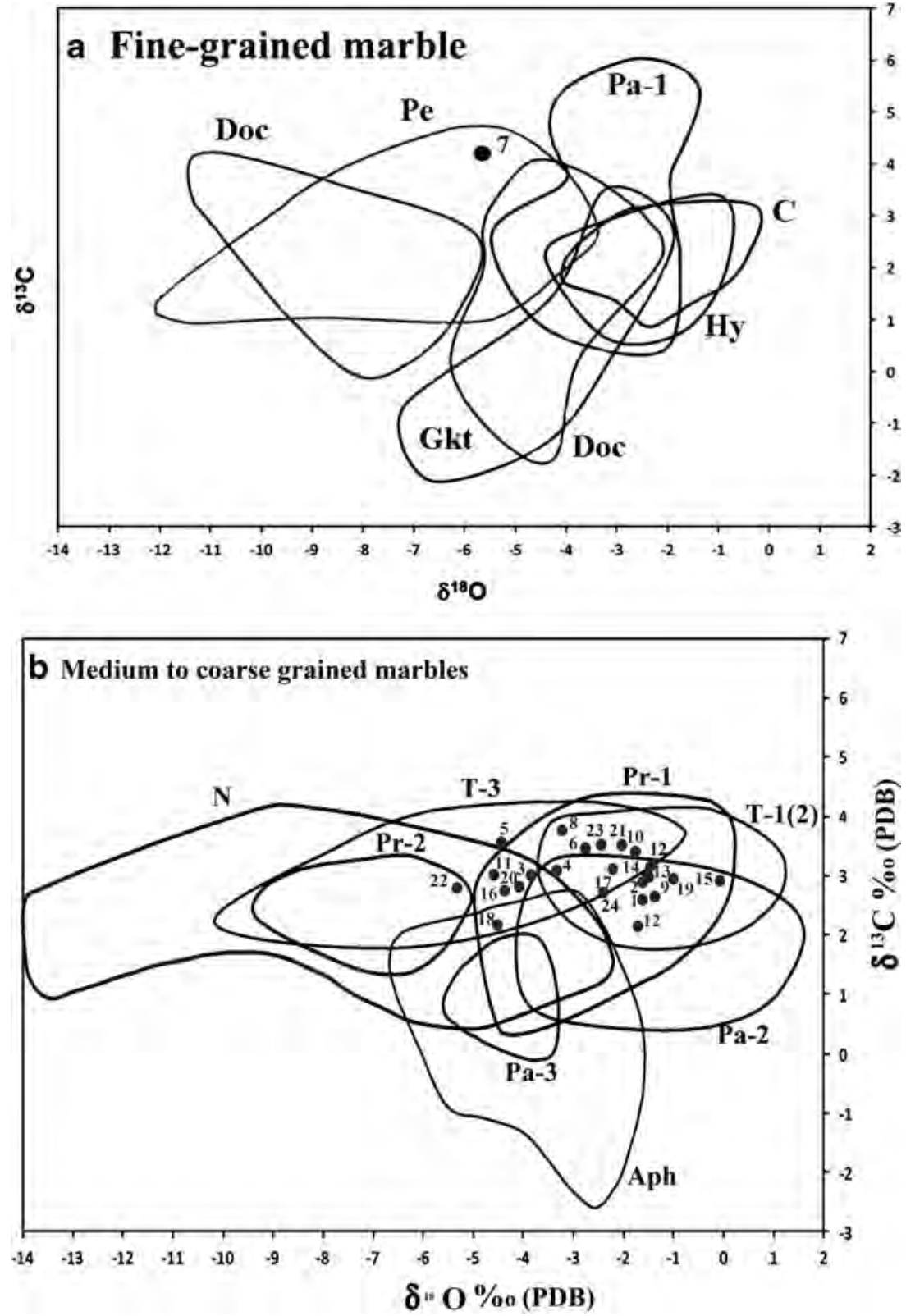

(Fig. 6). All of these petrographic features resembling those of Proconnesus-1 marble indicate that the most probable source of the marbles is Proconnesus-1, Marmara Island, Turkey.

\section{Discussion and conclusions}

Several samples plot in overlapping isotopic regions, but pinpoint Thasos-1(2), Proconnesus-1, Paros-2, and others. The limited use of Thasian- 1(2) marbles (which are mosaic and often has lineated and strained grains) for decorations and architectural elements in the Roman Imperial times (Bruno et al. 2002b) suggests its exclusion from the probable sources of the studied marbles. However, the petrographic features of all the samples (distinctive mortar fabric, sutured to embayed carbonate crystal boundaries, deformed polysynthetic twinning, MGS of 2-4 mm) and color (white to light gray with parallel gray bands) exclude Paros- 2 marble which tend to have more regular and straight crystal boundaries and homeoblastic fabrics than Proconessus-1 marble. To the contrary of Proconessus-1 marble which was the primary marble of the Byzantine period, Parian marble was of limited use after the third or fourth century AD (during the Byzantine period) (Maniatis and Polikreti 2000; Bruno et al. 2002b; Fischer 2009, Herrmann et al. 2009). Heraclea/Melitus marbles that have some similar features of the studied samples were also excluded because of their local use during antiquity (Antonelli and Lazzarini 2015). Naxos marbles were also excluded 


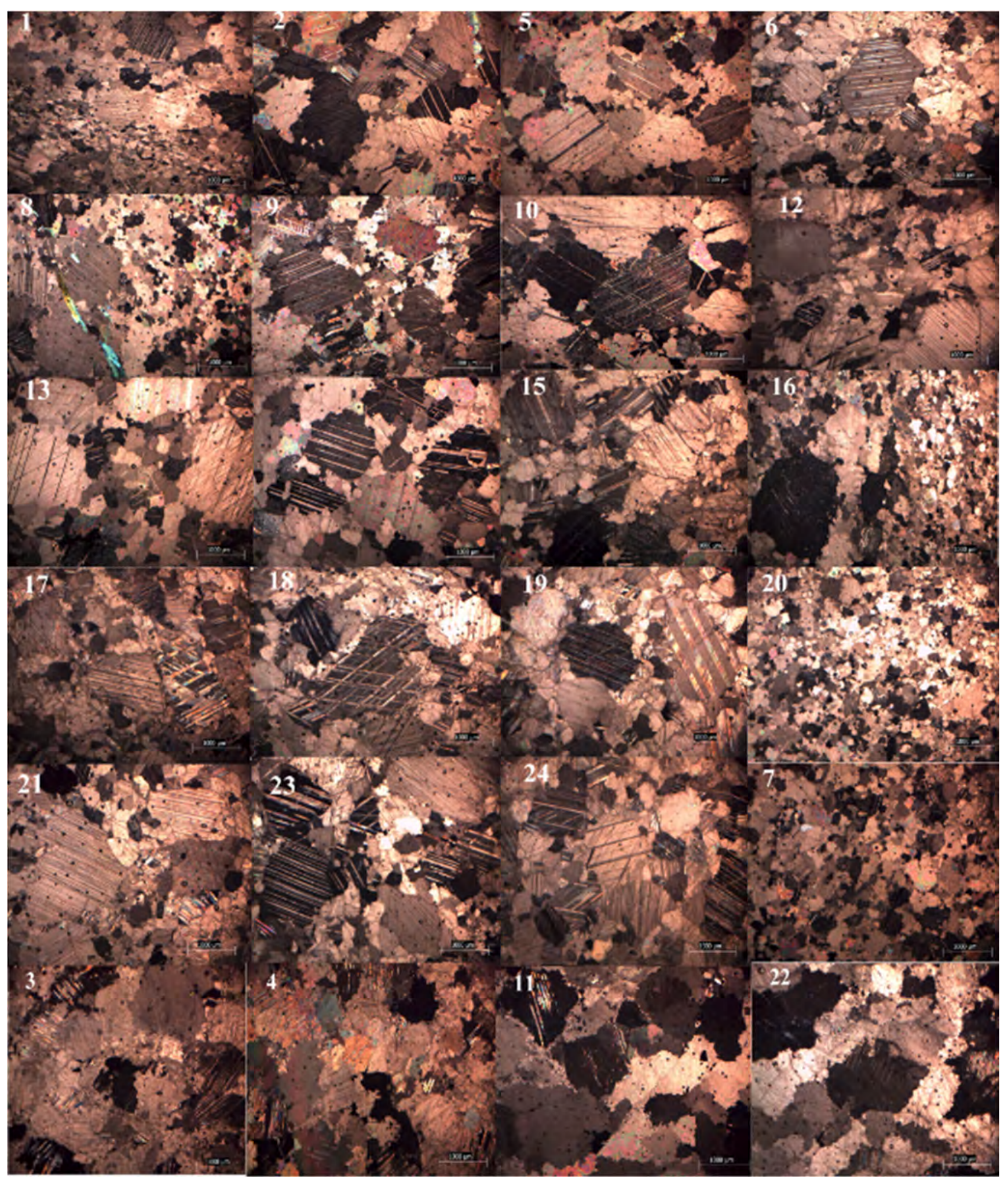

Fig. 6 Photomicrographs of thin sections detected in the white marble samples of the Udhruh extra-mural Byzantine Church: Sample 7 shows lineated fine grains with curve boundaries of Penteli marble, Samples 3,4,11,22 show Thasos-3 heteroblastic fabric made of coarse grained crystals having sutured boundaries, the remainder of the samples show heteroblastic coarse grains of embayed to sutured boundaries and the mortar fabric of Proconessus-1 white marble, sample 8,16, 20 has two grain size distributions and trains of muscovite (Proconessus-1), sample 18 shows elongated large calcite crystals (Proconessus-1) 
because their petrographic features are different from those of present samples. Furthermore, it is inconceivable that the marble samples under investigation used in one single building for architectural purposes were imported from different regions far from each other like Paros, Miletus, Naxos, and Proconnesus. The results of this research reflect the general trend of the wide use of Proconnesus marble (Marmara Island, Turkey) during the Byzantine period. The initial phase of building and using the church was during the fifth century $\mathrm{AD}$, the time of the spread of Christianity and the prosperity of the region (Watson 2001; Evans 2005). In fact, during the Byzantine period, Jordan witnessed the construction of many churches that were furnished and decorated with Proconnesus marble imported from Marmara Island (Al-Bashaireh and AlHousan 2015; Al-Bashaireh and Dettman 2015; Al-Bashaireh and Lazzarini 2016). This sort of marble was characterized by its availability, good quality, and low price, see for details Attanasio et al. (2008); Al-Bashaireh and Al-Housan (2015). The use of Proconnesus marbles at Udruh's church for pavements and decorations including panels, friezes, slabs, and chancel screen posts is in harmony with their traditional usage for architectural purpose (Fig. 4).

It is worth noting the similarities of the isotopic values of several Proconnesus-1 samples, as seen in Fig. 5 form distinct clusters. It is most probable that the samples of each cluster were cut from the same locus (or block) of the quarrying area and/or the same workshop. The results show the presence of two other types of marble but in limited numbers (1 sample from Penteli and 4 samples from Thasos-3). The difference in the quality and characteristics of the Penteli and Thasos- 3 marbles from those of Proconnesus-1 suggests special primary functions for them. The Penteli marble (sample 7) was used for a column most probably of a certain function that cannot be recognized with the available data. It is most probable that its function is related to one of the principal ritual practices of the church. It is unlikely that this Penteli column was used as a chancel screen post because of its difference in shape and color from the rest of the posts made of Proconnesus-1 marble. The Thasos-3 beige-colored marbles were used for fonts or basins which represent an important ritual element of the church's furniture for holding the water of the Baptism. It is likely that the small number of Penteli and Thasos-3 marble samples suggests a reworked spolia obtained from earlier buildings and has the pure distinctive white-beige color which is suitable for the ritual elements, although no proof of such marble elements have been retrieved from the adjacent Roman fort. This phenomenon of marble reuse was common during the Byzantine and early Islamic periods. Reuse of stones was reported by Al-Bashaireh and Lazzarini (2016) who found reused Paros-2 marble architectural elements and granite columns at the Cruciform Church of Abila, north Jordan.

The Proconessus-1 samples include chancel screen elements mainly posts and plates which were precisely produced by workshops organized by imperial or religious authority in finished or semi-finished states at the workshop of the quarry before shipping them to their final destination (Al-Bashaireh and Al-Housan 2015). Similar elements were uncovered in shipwrecks (Berlinghieri and Paribeni 2011) and field surveys at Proconnesus quarries (Asgari 1992). In addition, Habas (2009)'s stylistic analysis of chancel screen elements from Palestina and Arabia (including Jordan) found that most of them were imported.

It is very clear that the visual aspects and shape were the most important factors for the selection of the marble's quality and color for such important ritual elements. However, the gray Proconnesus-1 marble represents the most popular marble uses for ecclesiastical elements during the Byzantine period.

Acknowledgements The results of the Udhruh archeological project and this paper were not possible without the work and assistance of our team and students. We would like to thank Maarten Sepers and Roeland Emaus for the figures, Frans Theuws for his continuous support and assistance, and Willem Willems ( $\dagger$ ) whose support was essential for the establishment and the international joint venture of the Udhruh Archeological Project. This research project would not have been possible without the financial support of the Stichting Van Moorsel and Rijnierse (via the Netherlands Institute for Scientific Research-NWO).

\section{References}

Abudanh F (2006) Settlement patterns and military organisation in the region of Udhruh (Southern Jordan) in the Roman and Byzantine periods. Unpublished PhD-thesis Newcastle upon Tyne University. Newcastle upon Tyne

Al-Bashaireh K (2013) Plaster and mortar radiocarbon dating of Nabatean and Islamic structures, South Jordan. Archaeometry 55(2):329-354

Al-Bashaireh K, Al-Housan AQ (2015) Provenance investigation of white marbles of chancel screens from Rihab Byzantine churches, Northeast Jordan. J Cult Herit 16(4):591-596

Al-Bashaireh K, Al-Housan AQ (2019) Provenance of marble elements from the middle Church at Hayyan Al-Mushrif, Northeast Jordan: a multidisciplinary approach. Archaeol Anthropol Sci 11:2237-2247. https://doi.org/10.1007/s12520-018-0671-1

Al-Bashaireh K, Dettman D (2015) Geochemical analyses and provenance determination of white marble samples from churches in North Jordan. Bull Am Sch Orient Res 374:49-59

Al-Bashaireh K, Lazzarini L (2016) Marbles, granites and basalt used in the cruciform basilica of Abila (Decapolis, Jordan): archaeometric characterization and provenance. Archaeol Anthropol Sci 8(3):545554

Al-Salameen Z, Falahat H, Naimat S, Abudanh F (2011) New ArabicChristian inscriptions from Udhruh, southern Jordan. Arab Archaeol Epigr 22:232-242

Antonelli F, Lazzarini L (2015) An updated petrographic and isotopic reference database for white marbles used in antiquity. Rendiconti Lincei 26(4):399-413

Asgari N (1992) Obervation of two types of quarry items from Proconnesos: columnshafts and column bases. In: Waelkens $\mathrm{M}$, Herz N, Moens L (eds) AncientStones: Quarrying, Trade and Provenance, Acta Archaeologica Lovaniensia,Monograph, vol 4. Leuven University Press, Leuven, pp 73-80 
Attanasio D, Brilli M, Bruno M (2008) The properties and identification of marble from Proconnesos (Marmara Island, Turkey): a new database including isotopic, EPR and petrographic data. Archaeometry 50(5):747-774

Berlinghieri E C F and Paribeni A (2011) Byzantine merchant ships and marble trade: new data from central Mediterranean. In: Wien 2010, SKYLLIS 11, Proceedings of "In Poseidons Realm XV: Byzantium at Sea. Innovation Tradi-tion", 64-75

Brünnow RE, von Domaszewski A (1904) Die Provincia Arabia: auf Grund zweier in den Jahren 1897 und 1898 ünternommenen Reisen und der berichte früherer Reisender: Vol. 1. - Die Römerstrasse von Mâdebâ über Petra und Odruh bis El-'Akaba. Verlag Trübner, Strassburg

Bruno M, Conti L, Lazzarini L, Pensabene P, Turi B (2002a) The marble quarries of Thasos: an archaeometric study. In: Lazzarini L (ed) Interdisciplinary Studies on Ancient Stone - ASMOSIA VI, Proceedings of the Sixth International Conference of the Association for the Study of Marble and Other Stones in Antiquity, Venice, June 15-18, 2000, Padua, pp 157-162

Bruno M, Cancelliere S, Gorgoni C, Lazzarini L, Pallante P, Pensabene P (2002b) Provenance and distribution of white marbles in temples and public buildings of Imperial Rome. In: Interdisciplinary Studies on Ancient Stone - ASMOSIA VI, Proceedings of the Sixth International Conference of the Association for the Study of Marble and Other Stones in Antiquity, Venice, June 15-18, 2000, Padua, pp 289-300

Craig H (1957) Isotopic standards for carbon and oxygen and correction factors for mass-spectrometric analysis of carbon dioxide. Geochim Cosmochim Acta 12(1-2):133-149

Evans JA (2005) The Emperor Justinian and the Byzantine Empire. Greenwood guides to historic events of the ancient world. Greenwood, Westport

Fiema Z (2002) Late-antique Petra and its hinterland: recent research and new. In: Humphrey JH (ed) The Roman and the byzantine near east, Ann Arbor: journal of Roman archaeology supplement series, vol 49, pp 191-252

Fischer M (2009) Marble from Pentelicon, Paros, Thasos and Proconnesus in ancient Israel: an attempt at a chronological distinction. In: Maniatis Y (ed) ASMOSIA VII: Proceedings of the 7th International Conference of Association for the Study of Marble and Other Stones in Antiquity, Organized by the French School of Athens, the National Center for Scientific Research "Dimokritos," the 18th Ephoreia of Prehistoric and Classical Antiquities (Kavala), and the Institute of Geology and Mineral Exploration, Thassos, September 15-20, 2003, vol Supplement 51. Bulletin de correspondance hellénique, Athens, pp 399-412

Frösén J (2004) Archaeological information from the Petra papyri. Stud Hist Archaeol Jord 8:141-144

Gaggadis-Robin V, Sintès C, Kavoussanaki D, Dotsika E, Maniatis Y (2009) Provenance investigation of some marble sarcoph-agi from Arles with stable isotope and maximum grain size analyses. In: Maniatis Y (ed) ASMOSIA VII: Proceedings of the 7 th International Conference of Association for the Study of Marble and Other Stones in Antiquity, Organized by the French School of Athens, the National Center for Scientific Research "Dimokritos," the 18th Ephoreia of Prehistoric and Classical Antiquities (Kavala), and the Institute of Geology and Mineral Exploration, Thassos, September 15-20, 2003, vol Supplement 51. Bulletin de correspondance hellénique, Athens, pp 133-146

Glueck N (1935) Explorations in eastern Palestine II. Annu Am Sch Orient Res 15:60-80

Gorgoni C, Lazzarini L, Pallante P, Turi B (2002) An updated and detailed mineropetrographic and $\mathrm{C}-\mathrm{O}$ stable isotopic reference database for the main Mediterranean marbles used in antiquity. In: Herrmann JJ Jr, Herz N, Newman R (eds) Interdisciplinary studies on ancient stone, ASMOSIA 5, Proceedings of the fifth international conference of the association for the study of marble and other stones in antiquity, Museum of Fine Arts, Boston, June, 11-15, 1998. Archetype Publications, London, pp 115-131

Habas L (2009) The art of imported marble chancel screens and its influence onlocal production in the churches of the provinces of Palaestina and Arabia:a case study. In: Oniz H (ed) SOMA, Proceedings of the XII Symposium on Mediterranean Archaeology, Famagusta, North Cyprus, 5-8 March 2008, British archaeological reports international series 1909. Archaeopress, Oxford, pp 100-108

Herrmann Jr., J. J. and R. Newman, 2002. New sculptures in Thasian dolomite: Turkey, Greece, Egypt, Italy. In: J. J. Herrmann Jr, N. Herz and R. Newman (eds.), Interdisciplinary studies on ancient stone, ASMOSIA 5, Proceedings of the fifth international conference of the association for the study of marble and other stones in antiquity, Museum of Fine Arts, Boston, June, 11-15, 1998. London: Archetype Publications, 215-224

Herrmann Jr., J. J., Tykot R. and Van Den Hoek A. 2009. Parian marble in Early Christian times. In: Y Maniatis (ed.), ASMOSIA VII: Proceedings of the 7th International Conference of Association for the Study of Marble and Other Stones in Antiquity, Organized by the French School of Athens, the National Center for Scientific Research "Dimokritos," the 18th Ephoreia of Prehistoric and Classical Antiquities (Kavala), and the Institute of Geology and Mineral Exploration, Thassos, September 15-20, 2003. Athens: Bulletin de correspondance hellénique Supplement 51, 723-737

Kennedy DL, Falahat H (2008) CastraLegionis VI Ferratae: a building inscription for the legionary fortress at Udruh near Petra. J Roman Archaeol 21:150-169

Killick A (1983) Udruh - the frontier of an empire. Levant 15:110-131

Killick A (1986) Udruh and the southern frontier. In: Freeman P, Kennedy D (eds) The defense of the Roman and Byzantine east, British archaeological reports international series, vol 297. Archaeopress, Oxford, pp 431-446

Killick M (1990) Les Nabatéens à Udhruh. ARAM Period 2(1-2):249252

Lazzarini L (2004) Characterisation of the white marble of two unpublished ancient roman quarries on the islands of Fourni and Skyros (Greece). Period Mineral 69(1):49-62

Maniatis Y, Polikreti P (2000) The characterisation and discrimination of Parian marble inthe Aegean region. In: Schilardi DU, Atsonopoulou DK (eds) Paria Lithos, proceedings of 1st international conference on the archaeology of Paros and the Cyclades, Paros, October 2-5, 1997, Athens, pp 575-584

Roos P, Moens L, de Rudder J, de Paepe P, van Hende J, Waelkens M (1988) Chemical and petrographical characterisation of Greek marbles from Pentelikon, Naxos, Paros and Thasos. In: Herz N, Waelkens M (eds) Classical marble: geochemistry, technology, trade, vol 153. NATO ASI series, series E: applied sciences, Dordrecht, pp 263-272

Vincent L-H (1898) Notes de Voyage. Rev bibl Int 7(3):424-451

Watson P (2001) The Byzantine period. In: MacDonald B, Adams R, Bienkowski P (eds) The archaeology of Jordan, vol 1. Levantine archaeology, Sheffield, pp 461-502

Publisher's note Springer Nature remains neutral with regard to jurisdictional claims in published maps and institutional affiliations. 